\title{
APLIKASI SISTEM INFORMASI LOWONGAN KERJA BERBASIS INTERNET
}

\author{
Ilham M.Said \\ Program Studi Teknik Informatika - Universitas Muhammadiyah Gresik
}

\begin{abstract}
Abstrak
Sistem Informasi Lowongan Kerja Berbasis Internet yang hasil akhirnya berupa sebuah situs web adalah sistem yang menyediakan informasi lowongan kerja untuk para pencari kerja. Sistem ini juga memberikan informasi calon kandidat kepada perusahaan yang membutuhkan tenaga kerja, yang selanjutnya akan mempengaruhi pihak manajemen dalam pengambilan keputusan tentang lowongan kerja yang ditawarkan. Dengan fasilitas dan jaminan validasi terhadap data, sistem ini akan menjadi sebuah forum komunikasi yang efektif dan efisien antara pencari kerja dan penyedia kerja, serta mampu menembus batas-batas yang telah lama menjadi kendala yang cukup berarti, baik bagi perusahaan pencari tenaga kerja yang sulit mendapatkan orang yang tepat maupun bagi pencari kerja

yang disulitkan dengan mempersiapkan syarat-syarat pengajuan lamaran serta mengejar batas waktu yang ditentukan.
\end{abstract}

Kata kunci : informasi dan internet

\section{A. PENDAHULUAN}

Pengembangan sistem informasi lowongan kerja berbasis internet merupakan suatu usaha untuk menghasilkan sebuah sistem informasi yang mampu menyediakan informasi yang berhubungan dengan dunia kerja, terutama lowongan kerja, baik kepada para pencari kerja (job seekers) maupun bagi perusahaan pencari tenaga kerja (pemberi kerja, employers) yang dapat diakses melalui internet. Internet sendiri adalah suatu jaringan global yang terhubung lewat saluran komunikasi berkecepatan tinggi (Dornfest, 1997). Internet menyatukan jaringan-jaringan komputer milik universitas-universitas, perusahaanperusahaan, institusi-instiusi pemerintah dan swasta, dan sebagainya (Setiawan, 1996). Orang-orang yang menggunakan internet dapat saling berkomunikasi dan berbagi informasi, dimana pun mereka berada. Bagi para pencari kerja, mempersiapkan syarat-syarat pengajuan lamaran kerja seperti Curriculum Vitae yang terus berubah, mengejar batas waktu pengiriman lamaran serta besarnya biaya pengiriman berkas tercetak (kertas) saat ini merupakan kendala yang sangat berarti. Selain itu, para pencari kerja juga harus rajin mengkoleksi surat kabar untuk mendapatkan lowongan kerja yang sesuai dengan harapannya. Jika diperhatikan secara seksama, pengorbanan yang paling nyata dalam mencari kerja adalah waktu dan uang. 
Pada bagian lain, perusahaan yang membutuhkan tenaga kerja baru juga harus menyediakan dana rutin perusahaan untuk pemasangan iklan lowongan kerja di mediamedia cetak. Setelah surat lamaran dari para pencari kerja diterima, perusahaan melakukan seleksi dan kemudian melayangkan surat panggilan kepada pelamar kerja yang dianggap layak.

\section{B. MAKSUD DAN TUJUAN PENELITIAN}

Maksud dan tujuan penulis melakukan penelitian tentang pengembangan sistem informasi lowongan kerja berbasis Internet adalah:

1. Memahami mekanisme komunikasi client/server jaringan Internet

2. Menghasilkan sebuah sistem informasi lowongan kerja berbasis Internet yang mampu menyediakan informasi secara cepat dan terjangkau untuk seluruh pengguna Internet

3. Mengimplementasikan ilmu yang mengenai jaringan komputer, sistem informasi, dan basis data.

\section{METODE PENELITIAN}

Metode yang penulis lakukan untuk memperoleh hasil yang diharapkan selama penelitian adalah sebagai berikut :

1. Studi literatur, terutama yang berkaitan dengan sistem informasi, basis data, dan pemrograman Internet.

2. Menyiapkan server Intranet menggunakan sistem operasi Linux Mandrake versi 7.2 yang telah dilengkapi bahasa pemrograman PHP3, server basis data MySQL, dan server web Apache. Penulis juga menginstal dua komputer client berbasis Windows 98 dan Windows 2000.

3. Mendesain dan menulis kode prototype sistem informasi lowongan kerja berbasis Internet.

4. Menempatkan prototype di server Internet gamanet.ugm.ac.id yang dapat diakses dari semua komputer yang terhubung ke Internet.

5. Diskusi dengan pembimbing, pengguna Internet terutama pemrogram web dan Network Administrator Linux

Sedangkan alat-alat, baik perangkat keras maupun perangkat lunak yang digunakan dalam penelitian ini adalah :

1. Tiga komputer personal yang dilengkapi kartu jaringan (ethernet)

2. Linux Mandrake 7.2 sebagai sistem operasi

3. PHP3 sebagai bahasa pengembangan

4. MySQL sebagai server basis data

5. Apache sebagai server World Wide Web

6. Beberapa editor HTML pada sistem operasi Linux dan Windows

\section{TINJAUAN PUSTAKA}

\section{Informasi dan Data}

Informasi adalah data yang telah diolah menjadi sebuah bentuk yang berarti bagi penerimanya dan bermanfaat dalam pengambilan keputusan saat ini atau mendatang (Davis, 1974). Sedangkan data, sebagai bahan baku informasi, didefinisikan sebagai 
kelompok simbol-simbol yang teratur yang mewakili kuantitas, tindakan, benda dan sebagainya. Data ini dapat diolah dalam bentuk struktur data, struktur file atau basis data (database) (Davis, 1974).

Sistem informasi adalah suatu kombinasi dari orang-orang, fasilitas, teknologi, media, prosedur-prosedur dan pengendalian yang ditujukan untuk mendapatkan jalur komunikasi penting, memproses tipe transaksi rutin tertentu, memberi sinyal kepada manajemen dan yang lainnya terhadap kejadian-kejadian internal dan eksternal dan menyediakan suatu dasar untuk pengambilan keputusan yang cerdik (Davis, 1974).

\section{Internet}

Internet adalah jaringan global yang terhubung lewat saluran komunikasi yang berkecepatan tinggi (Dornfest, 1997). Internet menyatukan jaringan-jaringan komputer milik universitas-universitas, perusahaan-perusahan, institusi-institusi swasta dan sebagainya (Setiawan, 1996). Internet juga mencakup komputerkomputer pribadi yang dihubungkan dengannya. Internet dapat dianggap sebagai super jaringan, suatu jaringan dari jaringan-jaringan komputer. Peserta-peserta Internet dapat saling berkomunikasi dan berbagi informasi, di mana pun mereka berada, juga seandainya mereka berada di negeri atau bahkan di benua yang berlainan.

\section{E. RANCANGAN SISTEM \\ Prosedur Pengembangan}

Sebuah sistem informasi yang berbasis internet termasuk sebuah perangkat lunak. Oleh karena itu prosedur pengembangannya adalah prosedur pengembangan perangkat lunak. Terdapat dua model pengembangan perangkat lunak yang banyak dipakai, yaitu linear sequential model dan prototyping model (Pohan, 1997). Yang menjadi dasar langkah pengembangan sistem informasi lowongan kerja berbasis internet ini adalah linear sequential model. Meskipun begitu, pengembangan sistem informasi ini juga mengadopsi prototyping model, ini karena pengembangan dilakukan untuk mendapatkan sebuah prototype terlebih dahulu, yang kemudian dikembangkan untuk mendapatkan sistem yang lengkap dan lebih baik, dari sisi fasilitas maupun kemudahan dan kecepatan.

Prosedur yang dilakukan dalam pengembangan sistem informasi lowongan kerja berbasis internet ini meliputi :

1. Penggalian informasi dari calon pengguna (survey)

2. Analisis sistem

3. Penentuan modul-modul

4. Penulisan kode program yang menghasilkan prototype

5. Pengetesan prototype

6. Pengembangan prototype menjadi produk yang lebih baik dan lengkap.

Tahap-tahap penggalian informasi dari calon pengguna, analisis sistem dan penentuan modul-modul merupakan tahap-tahap yang dimaksud sebagai fase perencanaan, sedangkan penulisan kode, yang tahap pertama menghasilkan prototype dan selanjutnya akan memperbaiki prototype sehingga diperoleh produk yang lebih baik dan lengkap, dimasukkan ke fase implementasi. 


\section{Rancangan Pengguna dan fasilitas}

Sistem ini membagi penggunanya dalam empat kategori, yaitu pengguna tidak terdaftar, pencari kerja, pemberi kerja serta administrator sistem. Semua kategori pengguna dapat berinteraksi dengan sistem, tetapi dalam tingkatan akses yang berbeda. Berikut ini adalah fasilitas-fasilitas yang tersedia untuk pengguna :

A. Fasilitas Pengguna Tidak Terdaftar

1. Menjelajah situs web sistem informasi lowongan kerja dengan memanfaatkan link-link yang tersedia pada situs sistem.

2. Mendapatkan lima (jika ada) informasi lowongan kerja terbaru untuk semua jenis bidang kerja

3. Mendapatkan informasi terbaru tentang dunia kerja

4. Mencari lowongan kerja berdasarkan kriteria tertentu, phrase

5. Mencari lowongan kerja berdasarkan bidang kerja

6. Mencari lowongan kerja di situs lain, yang disediakan sistem ini

7. Mendaftarkan perusahaan menjadi anggota pemberi kerja

8. Mendaftarkan diri menjadi anggota pencari kerja

9. Mencari tahu tersedia atau tidak lowongan kerja di suatu perusahaan

10. Berlangganan informasi praktis dunia kerja menggunakan e-mail.

B. Fasilitas Pemberi Kerja

1. Memasang iklan lowongan kerja baru

2. Mengedit iklan lowongan yang ada

3. Mengedit data perusahaan

4. Mencari kandidat yang dibutuhkan dengan cepat, memanfaatkan wizard yang disediakan sistem.

5. Mencari kandidat memanfaatkan text box (phrase tertentu)

6. Keluar dari keanggotaan secara on-line (unsubscribe)

7. Mengirim e-mail kepada pencari kerja tertentu

8. Log-out jika selesai mengakses sistem

C. Fasilitas Pencari Kerja

1. Mengedit data pribadi anggota, Curriculum Vitae

2. Mengedit data minat pekerjaan yang diharapkan

3. Menerima lowongan kerja seketika lewat email (job alert e-mail)

4. Mengirim aplikasi lamaran kerja secara on-line

5. Mendapatkan informasi lowongan kerja terbaru sesuai minat kerja

6. Keluar dari keanggotaan secara on-line (unsubscribe)

7. Log-out setelah selesai mengakses sistem

8. Semua fasilitas pencarian yang diberikan untuk pengguna tidak terdaftar

D. Fasilitas Administrator

1. Memeriksa basis data secara keseluruhan

2. Menghapus data tertentu yang ada dalam basis data 
3. Menonaktifkan anggota yang diinginkan

4. Menjalankan modul pengiriman job alert e-mail

5. Mengubah data tertentu dalam basis data, misal mengubah kode propinsi dan kode bidang kerja

6. Menambah data tertentu ke dalam basis data

7. Menghapus atau mengubah struktur tabel yang diinginkan

\section{Cara Kerja Sistem}

Sistem informasi yang akan dibangun mempunyai beberapa komponen penting, yaitu : web server, mail server, database engine dan bahasa PHP3 di sisi server dan terdapat web browser dengan segala kelebihan dan kekurangannya di sisi client. Sistem ini membagi pengguna ke dalam empat jenis, dimana setiap jenis pengguna mempunyai hak yang berbeda. Tiga jenis pengguna : tidak terdaftar, pencari kerja dan pemberi kerja, hanya dapat mengakses sistem dari internet, sedang pengguna terakhir, yaitu administrator hanya dapat mengakses sistem dari LAN (jaringan komputer lokal).

Berikut adalah perkiraaan cara kerja sistem yang terhubung ke Internet :

1. Pengunjung mengakses situs sistem dengan alamat http://www.nama_server.domain/menggunakan web browser.

2. File utama (index, biasanya index.html atau index.php3) dipanggil oleh web server

3. Karena merupakan rutin-rutin PHP3, maka web server memanggil interpreter PHP3

4. Jika rutin-rutin tersebut memerlukan koneksi ke database engine (server), maka dibuat koneksi ke database server.

5. Jika rutin-rutin tersebut mengandung perintah pengiriman e-mail ke alamat e-mail tertentu, maka tugas pengiriman e-mail tersebut diserahkan ke mail server.

6. Jika ada data yang diminta, maka database server mengembalikan data yang diminta tersebut.

7. PHP mengurai data yang di dapat dari database server dan mengembalikan informasi yang diminta ke web server.

8. Web server memberi data yang diminta client jika data tersebut tersedia.

\section{Basis Data}

Sistem ini menyimpan data-data yang diperlukan. Tabel-tabel tersebut adalah :

1. PemberiKerja. Tabel ini menyimpan data mengenai sebuah perusahaan, seperti nama perusahaan.

2. PencariKerja. Tabel ini menyimpan data-data yang berhubungan dengan anggota pencari kerja seperti nama lengkap dan tanggal lahir.

3. Alamat. Tabel ini menyimpan data alamat lengkap dari anggota pemberi kerja dan pencari kerja.

4. Login. Tabel ini menyimpan data-data yang digunakan sebagai kunci untuk dapatmelakukan login dan menggunakan sistem, baik untuk anggota pemberi kerja dan pencari kerja, juga digunakan untuk melakukan pengamanan data yang ada di dalam sistem.

5. Minat Kerja. Tabel ini menyimpan data-data minat pekerjaan yang diinginkan oleh anggota pencari kerja. 
6. Keahlian. Tabel ini berisi informasi lengkap tentang pendidikan dan pengalaman kerja anggota pencari kerja.

7. Lowongan. Tabel ini menyimpan informasi lengkap suatu informasi lowongan kerja yang dipublikasikan oleh anggota pemberi kerja.

8. InfoDuniaKerja. Tabel ini berisi informasi dunia kerja atau mengenai situs sistem informasi lowongan kerja berbasis internet ini.

9. GajiBulanan. Tabel ini menyimpan daftar gaji bulanan yang disediakan oleh sistem.

10. PelangganInfo. Tabel ini menyimpan semua pelanggan informasi terbaru mengenai dunia kerja.

11. ProgramStudi. Tabel ini menyimpan daftar semua program studi yang diperlukan oleh anggota pemberi kerja dan pencari kerja.

12. BidangKerja. Tabel ini menyimpan daftar semua bidang kerja yang ada.

13. Kualifikasi. Tabel ini menyimpan daftar kualifikasi yang ada dalam dunia kerja saat ini, terutama untuk jenjang pendidikan tinggi (perguruan tinggi), mulai dari Mahasiswa, Diploma I (D1) sampai Strata III (S3).

14. Counter. Tabel ini menyimpan data counter, yaitu jumlah situs sistem ini diakses oleh pengunjung

15. Saran. Tabel ini menyimpan data-data saran dan kritik yang disampaikan oleh pengguna, baik terdaftar maupun tidak terdaftar.

16. LinkLain. Tabel ini menyimpan daftar situs yang dapat diakses oleh pengunjung.

\section{F. IMPLEMENTASI SISTEM}

\section{Modul-modul Sistem}

Interaksi antara pengguna dengan sistem ditangani oleh modul-modul, tiap modul menangani tugas yang spesifik. Modul-modul tersebut adalah sebagai berikut :

1. Penanganan log-in anggota, modul ini digunakan untuk menangani aksi log-in yang dilakukan anggota, baik pencari kerja maupun pemberi kerja, pemeriksaan terhadap userid dan password anggota serta menciptakan tanda log-in yang digunakan untuk security.

2. Perubahan data perusahaan, modul ini menangani perubahan data suatu perusahaan yang menjadi anggota pemberi kerja, seperti perubahan alamat perusahaan, deskripsi kerja, dan alamat e-mail.

3. Pemasangan dan perubahan informasi lowongan, modul ini menangani proses pemasangan informasi lowongan kerja baru serta proses editing (perubahan) terhadap informasi lowongan yang telah dimuatsebelumnya. Modul ini digunakan oleh pemberi kerja.

4. Perubahan minat kerja, modul ini digunakan untuk menangani perubahan minat pekerjaan yang diharapkan oleh pencari kerja terdaftar, seperti perubahan bidang kerja, program studi, dan gaji per bulan yang diharapkan.

5. Pemeriksaaan lowongan berdasar minat kerja, modul ini berguna untuk menangani permintaan informasi lowongan kerja terbaru dari pencari kerja yang sesuai dengan informasi yang diolah pada modul perubahan minat kerja.

6. Pengiriman aplikasi on-line, modul ini digunakan untuk menangani aksi pengiriman email yang dilakukan pencari kerja yang berisi aplikasi lamaran kerja ke perusahaan yang diharapkan, seperti Curriculum Vitae. 
7. Pencarian kandidat, modul ini digunakan untuk menangani aksi pencarian kandidat untuk suatu posisi yang diharapkan oleh perusahaan pemberi kerja. Modul ini juga menyediakan suatu fasilitas pengiriman e-mail kepada kandidat yang dianggap tepat.

8. Situs lain. Modul ini akan menampilkan semua situs penyedia informasi dunia kerja yang terdapat dalam basis data sistem.

9. Pendaftaran anggota baru, modul ini menangani proses pendaftaran menjadi anggota,baik sebagai pencari kerja maupun pemberi kerja, yang dilakukan oleh pengguna tidak terdaftar.

10. Pencarian informasi lowongan, modul ini digunakan untuk menangani permintaan informasi lowongan kerja terbaru berdasarkan pada bidang kerja, phrase tertentu dan perusahaan pemberi kerja, yang dapat dilakukan oleh pencari kerja dan pengguna tidak terdaftar.

11. Berlangganan berita, modul yang akan menangani proses pendaftaran untuk mendapatkan informasi / berita terbaru seputar dunia kerja, termasuk e-commerce

12. Job alert e-mail, modul ini akan mengirim informasi lowongan kerja yang bersesuaian dengan data minat kerja pencari kerja ke e-mail address pencari kerja ketika suatu informasi lowongan terbaru dimuat oleh pemberi kerja.

13. Pengisian informasi dunia kerja, modul ini digunakan untuk mengisi informasi terbaru seputar dunia kerja dan menangani proses pengiriman informasi tersebut kepada pengguna yang berlangganan.

\section{Perangkat Lunak yang Digunakan}

Sistem ini dibangun menggunakan bahasa web scripting PHP3 (Professional Home Page), sedangkan basis datanya ditangani oleh database engine MySQL. Untuk mendapatkan unjuk kerja terbaik bagi kedua software diatas, penulis menggunakan sistem operasi Linux Mandrake 7.2 yang telah dilengkapi web server Apache. Pemilihan keempat software diatas juga disebabkan sifat opensource-nya, gratis dan legal.

\section{G. PENUTUP}

Saat ini sistem yang dibangun telah ditempatkan di internet pada lokasi http://gamanet.ugm.ac.id/ ilham dan telah dapat digunakan dengan baik. Meskipun begitu, beberapa perbaikan diperlukan agar sistem lebih stabil dan tangguh serta yang paling penting adalah adanya jaminan validasi data yang terdapat pada sistem tersebut. Untuk itu penulis menyarankan hal-hal berikut ini untuk segera dilaksanakan jika sistem tersebut benar-benar akan digunakan secara optimal :

1. Tersedianya suatu badan atau organisasi yang berani menjamin validasi data yang terdapat dalam sistem, misalnya pihak universitas

2. Penempatan sistem di server internet yang lebih baik, yang memberikan layanan akses terhadap data lebih cepat.

3. Mempersiapkan orang-orang yang akan memanajemen sistem tersebut (staf administrasi)

4. Perbaikan pada sistem dari sisi bahasa pemrograman php ,seperti penambahan fasilitas untuk administrator sistem misalnya monitoring. Saran dan kritik dari pembaca juga sangat penulis harapkan. 


\section{H. DAFTAR PUSTAKA}

Atkinson, Leon., 1999, Core PHP Programming, Prentice Hall PTR.

Torben., Lerdorf, Rasmus., Suraski, Zeev., Zmievski, Andrei., 2000, PHP Manual, PHP Documentation Group

Davis, Gordon., 1974, Kerangka Dasar Sistem Informasi Manajemen, PT

Pustaka Binaman Pressindo.

Dornfest, Asha., 1997, Publikasi Web dengan Word, PT Elex Media Komputindo.

MySQL.com, 2000, MySQL Reference Manual, TcX AB, Detron HB and MySQL Finland AB.

Pohan, Husni Iskandar., Kusnassriyanto, Saiful Bahri., 1997, Pengantar Perancangan Sistem, Penerbit Erlangga

Purbo, Onno W., Maryanto, Dodi., Widodo, Widjil., Hubbany, Syahrial., 2000, Membangun Server Internet dengan FreeBSD, PT. Elex Media Komputindo

Silberschatz, Abraham., Korth, Henry F., Sudarsan, F., 1997, Database System Concepts, McGraw-Hill Series in Computer Science.

Sutanta, Edhy., 1996, Sistem Basis Data Konsep dan Perananya dalam Sistem Informasi Manajemen, Penerbit ANDI 